\title{
Leishmania donovani: Thionins, plant antimicrobial peptides with leishmanicidal activity
}

\author{
Marta Berrocal-Lobo , Antonio Molina , Pablo Rodríguez-Palenzuela . \\ Francisco García-Olmedo , Luis Rivas \\ Centro de Investigaciones Biológicas, Ramiro de Maeztu 9, E-28040 Madrid, Spain \\ Centro de Biotecnología y Genómica de Plantas (UPM-INIA), Departmento de Biotecnoiogía E. T. S. I. Montes, Campus de Montegancedo, Universidad Politécnica de Madrid. \\ Autopista M40 (Km. 38), 28223 Pozuelo de Alarcón. Modrid, Spain
}

Keywords:

Leishmanio

Plant antimicrobial peptide

Thionin

Defensin

Snakin

lipid transfer protein

\begin{abstract}
A B S T R A C T
The leishmanicidal activity of plant antibiotic peptides (PAPs) from the principal families, such wheat thionins, a barley lipid transfer protein and potato defensins and snakins were tested in vitro against Leishmania donovani. Only thionins and defensins were active against this human pathogen at a low micromolar range of concentrations. Thionins resulted as the most active peptides tested until now. They collapsed ionic and $\mathrm{pH}$ gradients across the parasite plasma membrane together with a rapid depletion of intracellular ATP without affecting mitochondrial potential. Hence the lethal effect of thionins was mostly associated to permeabilization of the plasma membrane leading to an immediate death of the parasite. The present work is the first evidence for leishmanicidal activity in plant peptides. Future prospects for their development as new antiparasite agents on human diseases are considered.
\end{abstract}

\section{Introduction}

Plants and animals produce antimicrobial peptides against their pathogens, either expressed constitutively or induced after pathogen contact (Jenssen et al., 2006). Most of these peptides, polycationic and amphipathic, cause cell lysis upon interaction with the phospholipid matrix of the plasma membrane (Shai, 2002). Animal linear antimicrobial peptides have been extensively studied on prokaryotes using chemically synthesized analogs (jenssen et al., 2006). Peptide specificity on prokaryotes is fairly understood and mainly based on the exposure of acidic phospholipids at the outer leaflet of their plasma membrane (Shai, 2002). However, most PAPs $^{1}$ that are active on phytopathogens such as thionins, defensins, lipid transfer proteins or snakins (Castro and Fontes, 2005; BerrocalLobo et al., 2002) are not linear, but possess multiple disulfide bonds which impose a more rigid structure and afford a higher stability of the peptide in the plant (Giudici et al., 2006). Recently a Pyrularia pubera thionin was synthesized chemically showing identical bactericidal activity in vitro as the native peptide (Vila-Perello et al., 2003). Approaches like that open new possibilities to the production of plant peptides to treat human infections. Surprisingly, the in vitro activity of PAPs has not been tested until now against Protozoa. For that reason the principal objective of present work was to test the activity of selected PAPs on Leishmania donovani promastigotes, the causative agent of human visceral Leishmaniasis. Leishmania promastigotes imposes important restrictions to the peptide activity. Their surface shows a high metalloproteinase activity, a thick anionic glycocalix with lipophosphoglycan, and a restrictive membrane repairing mechanism confined to the flagellar pocket (Handman, 1999). Different isoforms of thionins from wheat (Triticum aestivum), a barley (Hordeum vulgare) LTP2 (lipid transfer protein), a potato (Solanum tuberosum) defensin PTH1 and a potato snakin1, were tested against Leishmania promastigotes in vitro. In a further step, the mechanism of action of thionins, as the peptides with highest leishmanicidal activity, was studied. Some parameters related to the bioenergetic of the parasite and the membrane permeabilization, such as $\mathrm{pH}$, ATP levels, the mitochondrial membrane potential and the $\mathrm{H}^{+} / \mathrm{OH}^{-}$gradients were measured. Our work shows that PAPs previously active against phytopathogens are also effective against 
the human pathogen Leishmania. These results may foster the use of plant antimicrobial compounds as a new source of leishmanicidal agents.

\section{Materials and methods}

Promastigotes from L. donovoni strain (MHOM/SD/OO/1S-2D) were grown at $25^{\circ} \mathrm{C}$ in RPMl at $\mathrm{pH} 7.2$ as previously described (Luque-Ortega et al., 2003). A mixture of equimolar concentrations of the $\alpha-1, \alpha-2$ and $\beta$ type I thionins from wheat (Triticum aestivum) isoforms, a barley (Hordeum vulgare) LTP2 (lipid transfer protein) $\alpha-1$ isoform, and a PTH1 defensin and snakin1 from potato (Solonum tuberosum), were purified by HPLC as previously described (Caaveiro et al., 1997). Reagents were obtained from Merck (Darmstadt, Germany) or Sigma (St. Louis, MO). Antimicrobjal activity was measured by inhibition on MTT reduction by $L$. donovoni promastigotes as described [8]. Briefly, parasites at $2 \times 10^{7}$ cells $/ \mathrm{ml}$ were incubated at $24^{\circ} \mathrm{C}$ with different peptide concentrations for $2 \mathrm{~h}$. Afterwards, parasites were washed, resuspended in $100 \mathrm{\mu l}$ Hanks $+\mathrm{Glc}$ containing MTT $(0.5 \mathrm{mg} / \mathrm{mL})$, and incubated for $2 \mathrm{~h}$ at $24^{\circ} \mathrm{C}$. The resulting precipitated formazan was solubilized by SDS addition and read in a 450 Bio-Rad ELISA microplate with a $600 \mathrm{~nm}$ filter as previously described (LuqueOrtega et al., 2003). For proliferation experiments, promastigotes $\left(2 \times 10^{7} \mathrm{cells} / \mathrm{ml}\right)$ were incubated $2 \mathrm{~h}$ with the peptides, washed and resuspended $\left(2 \times 10^{6} \mathrm{cells} / \mathrm{ml}\right)$ in their culture medium. Proliferation was then estimated after $\mathbf{4 8} \mathrm{h}$ by MTT reduction as previously shown (Luque-Ortega et al., 2003). Experiments were done at least twice and samples were run in triplicate. $\mathrm{LC}_{50}$ and $\left[\mathrm{C}_{50}\right.$ values were calculated by Litchfield and Wilcoxon procedure as previously described (Luque-Ortega et al., 2003). Effect of thionins on membrane permeation and intracellular $\mathrm{pH}$ changes were reached using a $\mathrm{pH}$-sensitive fluorescence dye BCECF-AM, Leishmania promastigotes were preloaded with the BCECF-AM at $25^{\circ} \mathrm{C}$ in the dark and later washed. Drugs were added after fluorescence stabilization. Afterwards fluorescence was measured in a spectrofluorometer at 500-nm (excitation) and 525-10m (emission) as previously described (Luque-Ortega et al., 2003). Full permeabilization was reached with Triton X-100. The decrease in intracellular ATP drop caused by thionins was assessed by in vivo luminescence of promastigotes transfected with Photinus pyralis luciferase in presence of the membrane-permeable substrate DMNPE-luciferin. Luminescence was recorded in a Polarstar Galaxy microplate reader (Luque-Ortega et al., 2003).

\section{Results and discussion}

Thionins showed the highest activity among the different set of PAPs assayed showing $I_{50}=0.2(0.1-0.5) \mu \mathrm{M}$ and an $\mathrm{LC}_{50}=1.1$ $(0.9-1.3) \mu \mathrm{M}$ for parasite proliferation (Fig. 1a). Activity of thionin $\alpha-1$ isoform was almost identical to that of the type I mixture (data not shown). Amastigotes, the intracellular form of the parasite, were more resistant to thionins, with $\mathrm{LC}_{50}=46.3(36.6-59.2) \mu \mathrm{M}$, than promastigotes. As the expression of LPG and Gp63 is close to nil in amastigotes, the change in phospholipid composition rather than peptide structure, likely underlie this difference between those Leishmania stages. In terms of concentration the leishmanicidal activity of thionins is very similar to those described for a broad spectrum of bacteria, fungi or eukaryotic cells (Castro and Fontes, 2005). Defensin (PTH1) kills Leishmonia at higher concentrations than thionins with $\left[C_{50}=33.4(21.5-52.4) \mu \mathrm{M}\right.$ and $\mathrm{LC}_{50}=5.9(3.2-10.8) \mu \mathrm{M}$ (Fig. 1a). The fungal activity of radish defensin involved a specific membrane receptor, $\mathrm{Ca}^{2+}$ influx, and $G$ protein activity (Castro and Fontes, 2005). Whereas these or similar features exist in Leishmania, this would require further study.
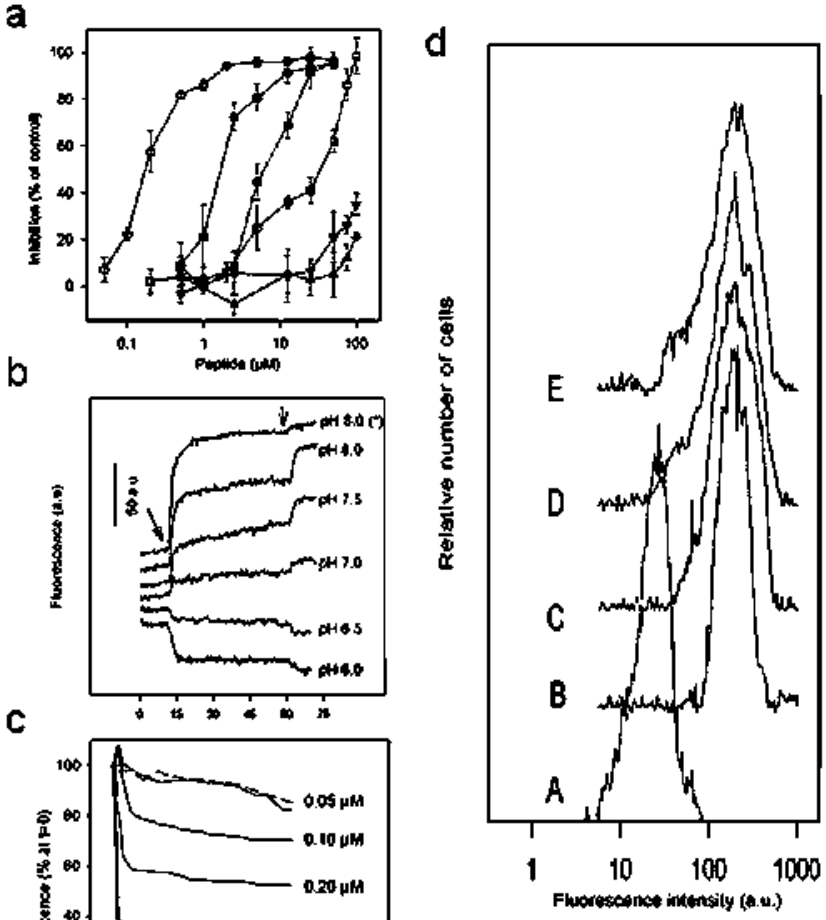

C
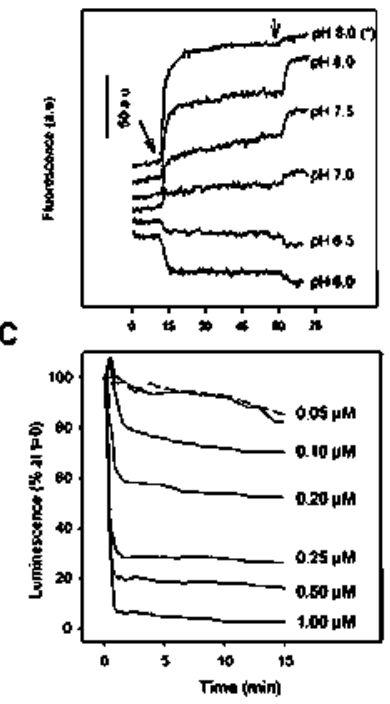

seonce intensily (a.u)

Fig. 1. (a). Inhibition of proliferation and MTT reduction of $L$. donovani promastigotes. Proliferation (solid symbols), MTT reduction (empty symbols). Type I thionins (circle), defensin PTH1 (square), LTP2 (triangle down) and snakin 1 (triangle up). (b) Dissipation of $\mathrm{H}^{+} / \mathrm{OH}^{-}$gradients across plasma membrane of $\mathrm{L}$. donovani promastigotes preloaded with BCECF-AM. The external $\mathrm{pH}$ is shown at the left side of the trace. left and right arrows stand for addition of $1 \mu \mathrm{M}$ thionin and Triton X-100, respectively. (*) Thionins $2 \mu \mathrm{M}$. (c) Intracellular ATP decrease after thionin addition assessed by luminescence in vivo on $L$. donovani promastigotes. Traces corresponding to the peptide concentrations are continuous. The luminescence of untreated parasites is shown as dotted trace. (d) Mitochondrial membrane potential of $L$ donovoni measured by rhodamine 123 accumulation after thionin treatment Traces: (A) Uncoupled parasites with $7.5 \mu \mathrm{M}$ FCCP; (B) Untreated parasites; (C-E) $0.5,1.0$ and $2.5 \mu \mathrm{M}$ thionins, respectively.

LTP2 and snakin1 were virtually inactive at the conditions tested; showing $\mathrm{LC}_{50}$ higher than $100 \mu \mathrm{M}$ (Fig. 1a).

Due to their highest activity, thionins were selected for a detailed study. This activity was dependent on temperature and $\mathrm{pH}$, decreasing dramatically below $25^{\circ} \mathrm{C}$ and $\mathrm{pH} 7$, respectively, and was inhibited by $\mathrm{Ca}^{2+}(94 \%$ inhibition at $1 \mathrm{mM})$, heparin and seroalbumin (Table 1), both known quenchers of hydrophobic compounds. Nevertheless, these conditions are far to be physiological for cell survival. However, thionin activity increased with ionic strength which, in some way, may promote higher hydrophobic interactions with parasitic membrane (Table 1). Depolarization by valinomycin only increased modestly the parasite survival, discarding membrane potential as an essential factor for thionin effectiveness (Table 1). At $1 \mu \mathrm{M}$ thionins dissipated $\mathrm{H}^{+} / \mathrm{OH}^{-}$gradients across the plasma membrane of Leishmania promastigotes, inducing a rapid equilibration between internal and external $\mathrm{pH}$. Total permeation was reached with Triton X-100 (right arrow at Fig. 1b). Furthermore, this permeation lead to drop in free intracellular ATP levels with $80 \%$ of their effect reached in just 2 min even at concentrations lower than their corresponding $\mathrm{IC}_{50}$ or $\mathrm{LC}_{50}$ (Fig. 1c). This quick kinetics supports the membrane permeability as an essential step in the lethal mechanism of thionins on Leish- 
Table 1

MTT reduction inhibition by thionins on $L$. donovari promastigotes tested.

\begin{tabular}{|c|c|}
\hline Changed condition respect standard ${ }^{a}$ & \% Inhibition (MTT reduction) \\
\hline $4 . \mathrm{C}$ & $6.3(3.5)$ \\
\hline $20^{\circ} \mathrm{C}$ & $32.6(5.6)$ \\
\hline $37^{\circ} \mathrm{C}$ & $85.3(8.7)$ \\
\hline $\mathrm{pH} 5.0$ & $56.5(3.5)$ \\
\hline $\mathrm{pH} 6.0$ & $54.8(8.3)$ \\
\hline $\mathrm{pH} 8.0$ & $80.3(6.1)$ \\
\hline $0.5 \mathrm{mM} \mathrm{Ca}^{2+}$ & $40.5(3.7)$ \\
\hline $1.0 \mathrm{mM} \mathrm{Ca}^{2+}$ & $62(4.6)$ \\
\hline $0.2 \mathrm{mg} / \mathrm{ml}$ Heparin & $5.1(7.4)$ \\
\hline $0.05 \mu \mathrm{M}$ Valinomycin & $80.3(4.5)$ \\
\hline $0.10 \mu \mathrm{M}$ Valinomycin & $65.7(5.1)$ \\
\hline $10 \mathrm{mg} / \mathrm{ml} \mathrm{BSA}$ & $3.5(2.6)$ \\
\hline $\mathrm{NaCl} 140 \mathrm{mM}, 0.2 \mu \mathrm{M}$ thionin & $63.7(4.5)$ \\
\hline $\mathrm{NaCl} 120 \mathrm{mM}, 0.2 \mu \mathrm{M}$ thionin & $52.5(6.5)$ \\
\hline $\mathrm{NaCl} 80 \mathrm{mM}, 0.2 \mu \mathrm{M}$ thionin & $6.7(4.5)$ \\
\hline $\mathrm{NaCl} 5 \mathrm{mM}, 0.2 \mu \mathrm{M}$ thionin & $8.4(2.3)$ \\
\hline
\end{tabular}

+ Standard conditions: $24{ }^{\circ} \mathrm{C}, \mathrm{pH} 7.0,140 \mathrm{mM} \mathrm{NaCl}, 0.5 \mu \mathrm{M}$ thionins; \% Inhibition (MTT reduction): $76.3(6.7)$.

mania as reported for other membrane-active compounds (LuqueOrtega et al., 2003). Additionally, it makes unlikely the establishment of mixed disulfides bounds between key metabolic enzymes and thionins previously described in vitro as essential for lethality [10]. Furthermore the maintenance of electrochemical potential in mitochondria, at least for a time range where the drop in free ATP takes place, ruled out the inhibition of thionins on mitochondrial ATP synthesis, as described for histatin 5 in Leishmania (Luque-Ortega et al., 2008) (Fig. 1d). Cytotoxicity of Pyrularia thionin on mammalian cells required $\mathrm{Ca}^{2+}$ influx and activation of endogenous PLA activity, likely by enhancing phospholipid accessibility to the enzyme (Evans et al., 1989). However, this is not the case for Leishmania, on which EGTA, $\mathrm{NiCl}_{2}$, verapamil (chelator and competitive and non-competitive inhibitors of $\mathrm{Ca}^{2+}$ channels, respectively), and dexamethasone (inhibitor of $P L A_{2}$ ), were unable to affect to the thionin activity (data not shown).

Plant thionins are among the highest efficient antimicrobial peptides tested against $L$. donovani promastigotes so far. This work and recent works related to thionin activity against other human pathogens (Vila-Perello et al., 2003; Stec, 2006) open new therapeutic possibilities to PAPs on human infectious diseases. Including that thionin activity, although lower, was still preserved on amastigotes, the effect on promastigote might be enough to stop the infection before happen. Further studies addressing the pharmacological applications of thionins and the therapeutic potentia] of their shorter synthetic analogs are currently in progress.

\section{Acknowledgments}

We thank Dr. Juan Román Luque-Ortega and Dra. Katrina Ramonell for critical reading of the manuscript. Mutated luciferase gene was kindly provided by Toni Aebischer.

This work was supported by research grants from the Consejo Superior de Investigaciones Científicas (CSIC; PIF 80F0171), Fondo de Investigación Sanitaria (FIS PI06115 and RD 06/0021/0006) to L.R., B]O2005-07198 to P.R.-P., BIO2005-07198, BI02003-4424 and B1O2006-00488 to A.M.

\section{References}

Berrocal-Lobo, M., Segura, A, Moreno, M, Lopez, G, Garcia-Olmedo, F, Molina, A. 2002. Snakin-2, an antimicrobial peptide from potato whose gene is locally induced by wounding and responds to pathogen infection. Plant Physiology $128,951-961$.

Caaveiro. J.M.M., Molina, A., González-Maìas, M.J., Rodríguez-Palenzuela, P., Garcíaolmedo, F, Goñi, F.M., 1997. Differential effects of five types of antipathogenic plant peptides on model membianes. FEBS Letters 410, 338-342.

Castro, M.S., Fontes, W. 2005. Plant defense and antimicrobial peptides. Protein Peptide letter 12, 13-18.

Evans, J., Wang. Y., Shaw, K.-P., Vernon, L.P., 1989. Cellular responses to Pyrularia thionin are mediated by $\mathrm{Ca} 2+$ influx and phospholipase $\mathrm{A} 2$ activation and are inhibited by thionin tyrosine iodination. Proceedings of the National Academy of Sciences of the United States of America 86. 5849-5853.

Giudici, M., Poveda, J.A, Molina, M.L., de la Canal, L, Gonzalez-Ros, J.M., Pfuller, K., Pfuller, U., Villalain, J., 2006. Antifungal effects and mechanism of action of viscotoxin A3. FEBS joumal $273,72-83$.

Handman, E., 1999. Cell biology of Leisimania. Advances in Parasitology 44, 1-39.

Jenssen, H., Hamill, P.. Hancock, R.E., 2006. Peptide antimicrobial agents. Clinical Microbiology Reviews 19, 491-511.

Luque-Ortega, J.R., Saugar. J.M., Chiva, C., Andreu, D., Rivas, L., 2003. Identification of new leishmanicidal peptide lead structures by automated real-time monitoring of changes in intracellular ATP. Biochemical joumal 375, 221-230.

Luque-Ortega, J.R., van't Hof, W., Veerman, E.C., Saugar. J.M., Rivas, L., 2008. Human antimicrobial peptide histatin $\mathbf{5}$ is a cell-penetrating peptide targeting mitochondrial ATP synthesis in Leishmania. FASEB Journal 22, 1817-1828.

Shai, Y., 2002. Mode of action of membrane active antimicrobial peptides. Biopolymers 66, 236-248.

5tec, B., 2006. Plant thionins - the structural perspective. Cell Molecular life Sciences 63, 1370-1385.

Vila-Perello, M., Sanchez-Vallet, A., Garcia-Olmedo, F., Molina, A., Andreu, D., 2003. Synthetic and structural studies on Pynioria pubera thionin: a single-residue mutation enhances activity against Gram-negative bacteria. FEBS Letters $\mathbf{5 3 6}$, 215-219. 